\title{
Text educational space: Old Russian pedagogical thought of the second half of $15^{\text {th }}-16^{\text {th }}$ centuries
}

\author{
Mikhail I. Makarov ${ }^{1, *}$ \\ ${ }^{1}$ ISED RAE, Laboratory of Theoretical Pedagogy and Philosophy of Education, 105062, Moscow, Russia
}

\begin{abstract}
The fragment of text educational space, associated with the advent of the first attempts of the secular interpretation of the meanings and significances of upbringing and their fixation in the Old Russian literature of the second half of $15^{\text {th }}-16^{\text {th }}$ centuries is considered in the paper. The researcher connects the changes appeared in text educational space of that chronographic period with social and political changes in Rus' (the old name for Russia-comment of the translator). Reflections of Old Russian authors about the ways of ethic rising of a human being and joining him to life as a continuous moral activity, studied in theoretical-methodological and historical-pedagogical way, are linked with pedagogical search of ways and methods of moral perfection and spiritual growth of a man.

The results of the research can be applied in the field of theory and history of pedagogy and philosophy of education.
\end{abstract}

In modern pedagogical science there is an ambiguous interpretation of the educational space. Among other definitions the pedagogical space is considered as a unified integrated formation that forms the duration of education with educational events and integrates the idea of training and upbringing. Clearly, in such a unified structure the educational subspaces can be allocated, among which the text educational space is allocated. This article represents an attempt to consider the episode of formation of text educational space, associated with the advent of the first attempts of the secular interpretation of the meanings and significances of upbringing and their fixation in the Old Russian literature sources of the second half of $15^{\text {th }}-16^{\text {th }}$ centuries.

The studies of how on different historic stages the formats of upbringing of a man acquired their unique shape, at present time is believed to be particularly significant for understanding history and modern state of pedagogical thought. From this point of view, it is considered to be important to address the literature sources, which accumulated stories, ideas, and thoughts about upbringing and study them through the prism of enlightening reflection, which in its way reveal the character and development of pedagogical thought.

The studies of Old Russian literature of the second half of $15^{\text {th }}-16^{\text {th }}$ centuries in the denoted view proves the existence of a significant part of pedagogical reflection in literature monuments of the given period. The choice of the chronological period and the interest towards it is conditioned by the fact that in literature monuments of the second half of $15^{\text {th }}-16^{\text {th }}$ centuries one can find the first attempts of secular interpretation of "teaching" points of upbringing.
Addressing the comprehension of secular meanings and significances of upbringing, we need to point out, that being a result of the fact that home pedagogical thought starting from $11^{\text {th }}$ century developed in the fold of Christianity, the notion "upbringing" from the moment of its appearance has been characterized from the point of view of theology, not pedagogy. Till the end of $17^{\text {th }}$ century the understanding of the upbringing phenomenon and pedagogical thought of Rus' itself were mainly concentrated in religious contemplation. That is why in numerous literature monuments (of living, teaching, eloquent, epic, annalistic, chronographic, patrological, apocryphal character) an idea was accumulated about upbringing of a man, who followed such a way of being, which prevented him from wrongdoings and gave him salvation from evil. But despite the fact that in Rus pedagogical ideas developed quite poorly, against the background of their weak development one could definitely see the connection between upbringing and the Christian idea of salvation.

There is an opinion that the notion "upbringing" has acquired the secular character and pedagogical status relatively recently, about 200 years ago in the Age of Enlightenment. Actually, in $18^{\text {th }}-$ the beginning of $19^{\text {th }}$ centuries the influence of Christian traditions on upbringing and education decreased. However, the first attempts of secular interpretation of "teaching" points of upbringing, as it was mentioned above, are discovered in Old Russian sources as early as in $15^{\text {th }}$ century.

At that time in Rus' the theological influence on all the spheres of mental activities and the development of heretical reformation-humanistic movements, which were 
focused on the interest towards secular and even nonChristian culture became significantly weaker.

The authors' reflections in appeared, so-called "useless novels", "non-Holy scriptures" about the education of a man as one of his virtues, about his moral growth, about useful role of knowledge and education in people's lives are full of secular "teaching" ideas.

It is interesting to mention the fact that in heretic "non-Holy scriptures", "useless novels" "teaching" the meanings are connected with humanistic attitude to a man, what is more, this humanism in the direct meaning of this word cannot be called Christian, as some radical representatives of heresy ran into denial of the future life, which is hearsay the view of practically atheistic character.

The appearance of secular meanings and meanings of upbringing is directly connected with social and political changes in Rus', which took place in the second half of $15^{\text {th }}-16^{\text {th }}$ centuries. These changes coincided with the changes in enlightening of this period, which can be judged according to a significant part of pedagogical thinking, reflected in literature of that time.

Besides the appearance of the first attempts of secular interpretation of "teaching" meanings of upbringing, in literature of the second half of $15^{\text {th }}$ century together with penetration of heretic reformation-humanistic ideas, connected with the interest towards some psychic states of a person with the understanding of a value of a human personality itself were reflected pedagogical reflections about the ways of ethic rising of a man and joining him to virtuous lifestyle, which differed by lively secular interpretations. These interpretations prove the weakening of a typical Middle-aged theological reign and the emerging of elements of "Russian Renaissance" in pedagogical interpretation of the ways of joining a man with a life as a continuous moral activity.

The signs of liberation from theological reign and of more "Renaissance" pedagogical comprehension of the ways of joining moral being are found in "Laodicea Message" by Fyodor Kuritzyn. The author of the message convincingly explains that education of a man is one of the virtues and informs that "here we come in the fear of God". By that the author of the message shows on the one hand, the way of moral rising of a man, on the other hand - focuses one's attention on the role of knowledge and education in his life.

Pointing out the author's interest of "Laodicea Message" to the questions of education, we would like to notice that in similar monuments of written language of the second half of $15^{\text {th }}$ century there are no clearly outlined ways and methods of pedagogical influence yet, though pedagogical narratives, which have the signs of developing into ways and methods of glorifying of desirable moral qualities in a man, can more or less be looked upon.

In this respect the written monument is remarkable, which has "practical" cognitive and didactic meaning, which is "Walking beyond the three seas" of Afanasii Nikitin. In that work, besides the author's reasoning about the impossibility of following Orthodox customs in the foreign land which are closely connected with everyday life, illustrating examples, which serve as an original "guide" on self-upbringing of love for Motherland, consisting of warm and kind attitude towards it and in belief of having justice established there: "In this world there is no other place like it [the Russian land A.N.]... Let the Russian land be established, and let justice be there" [1].

In another novel, but already with well-outlined fictional orientation "The novel about Drakula", one can find the reflections of ethical and pedagogical character about harmful, malicious lifestyle. The episodes of devil "evil" hero, besides artistic meanings, have implicit ethical and pedagogical meaning: the depiction of evil, harmful life matched the demand not to do what a hero does, and not to act so as he does, in other words, the illustration of malicious life imputed a man to not performing vices and the desire not to be vicious.

Another fiction "The novel about Dmitriy Basarg and his son Borzomysl" is rich in edification and didactics connected with imputing a man to fulfill moral deeds, in which the deeds of the youth Borzomysl match his devout aspiration for freeing people from the power of an evil tsar.

The appearance of such "tool" instructions and "tour guides" of ethic rising of a man in written language of the second half of $15^{\text {th }}$ century proved the fact that Old Russian pedagogical thought of that time differed by sufficient originality.

In $16^{\text {th }}$ century along with persecution of heretic movements and any forms of free thinking secular literature, lacking in features of "usefulness", that is "Holiness", was proclaimed forbidden, that is why pedagogical reflection about the ways of ethic rising of a man and joining him to virtuous life style were again presented within the limits of theological interpretations. However, this did not mean, that in such interpretations there were no humanistic or reformation ideas. Thus, in a newly appeared genre of historical narration, which "The Staid book of tsar genealogy" belongs to, "teaching" intentions are linked with the desire of the authors to change the previous true, distinguished by "non-virtuous" life stories of Russian princes and add high edification and didactics to them. This urge was caused by pragmatism in all views on history and human life and that role, which was given to a historical novel - not only did it draw attention to the history of the country, but also demonstrated examples of lives of historical personalities, examples, which were rich in pedagogical meanings.

In official chronicles of $16^{\text {th }}$ century, which "The staid book" was, it was impossible to depict "unworthy" examples of famous people's life. In this respect it is possible to conclude the "The staid book" as some other similar works, had ideological orientation, and ethical pedagogical part of this orientation played not the last role. "The staid book" played the role of a textbook of that time about joining a man to the life as a continuous moral activity. That is why all Russian princes in "The staid book" looked like in "godliness brightened", having "pleasing to God virtues" holy people.

In "The novel about Pyotr and Fevroniya" of Ermolay-Erasm implicitly presented pedagogical meaning is linked with illustrating of the beauty of a 
female's mind, nobility and gentleness - those virtues, which help the heroine to overcome evil actions of her strong rivals. In this book one can find an example of true love, as well as the high morality of marital fidelity and holy life. Ermolay-Erasm performed one of the first attempts to generalize the authors' thoughts existing in written language about the originality of a female life route and showed the way of ethic rising of a peasant, consisting of self-educating meekness, nobility, grace and Christian love. The originality of the "Novel about Pyotr and Fevroniya", besides literature merits, lies in the fact that didactic edifications of the novel's author were the pedagogical instructions for female upbringing and selfeducation. Thanks to that the novel gained deserved popularity in the practice of upbringing of "wise ladies".

The appearance of "peasant theme" in literature of $16^{\text {th }}$ century and its ethical and pedagogical interpretation showed the rooting of humanistic and reformation ideas in pedagogical thought of that time. Widely-spread and quite specific pedagogical discussion of "earthly" questions acquired more and more urgency and necessity. That is why ethical and pedagogical studying of this topic inevitably attracted attention of quite different authors. This was a breakthrough into another world: the world of didactic prose, focusing on literature fold ideas, thoughts about upbringing and studying them through the prism of pedagogical reasoning.

Along with that it could have been improperly to say that Old Russian literature of the second half of $15^{\text {th }}-$ $16^{\text {th }}$ centuries was full only of "pure" secular "teaching" meanings. The separation of religious beginning from "early" in pedagogical narrations and representations did not occur yet. The secularization of pedagogical though had just been outlined, thus in some novels one could find theological elements and poorly disguised edification. Nevertheless, the idea of upbringing of people, who are capable of building their life on reasonable grounds was more clearly distinguished and it had more theoretical basis.

The focus of attention on pedagogical problematics in Old Russian literature of the second half of $15^{\text {th }}-16$ th centuries reveals the accumulating of authors' interest towards enlightening issues connected, on the one hand, with joining a man outside his belonging to a particular class or corporation with the values of kindness, truth and beauty, on the other hand - with fruitful search of ideas and methods of upbringing, leading to the understanding of the essence of a human life as a continuous moral activity.

Concluding the consideration of the designated problem we would like to note that the Old Russian text educational space of the second half of $15^{\text {th }}-16^{\text {th }}$ centuries connected with the advent of the first attempts of the secular interpretation of meanings and significances of upbringing, as well as with the fixation of pedagogical paths of search and techniques of moral improvement and spiritual growth of human being reflected in the literary fabric of the chronographic interval.

\section{References}

1. A. Nikitin, Walking beyond the three seas (Moscow, 1948) 